\title{
Population demography of Oxymycterus rufus (Rodentia: Cricetidae) inhabiting a patchy environment of the delta of the Paraná River, Argentina
}

\author{
Victor R. CUETO, Martha J. PIANTANIDA and Marcela CAGNONI
}

Cueto V. R., Piantanida M. J. and Cagnoni M. 1995. Population demography of Oxymycterus rufus (Rodentia: Cricetidae) inhabiting a patchy environment of the delta of the Paraná River, Argentina. Acta Theriologica 40: 123-130.

We employed a live-trapping grid encompassing several discrete vegetation patches to analyze spatial differences in the demographic structure of an Oxymycterus rufus (Fischer, 1814) population living on the delta of the Paraná River, Argentina. Abundance, residence and reproduction of both females and males have been associated with microhabitats where food (measured through the availability of arthropods) was more abundant, and were not associated with the plant cover of those microhabitats. Our results emphasize the importance of food availability in the spatial distribution of resident and reproductive individuals, and hence in the survival and breeding success of their populations in the Paraná delta area.

Museo Argentino de Ciencias Naturales "Bernardino Rivadavia”, Av. Angel Gallardo 470, 1405, Buenos Aires, Argentina (VRC, MJP); Departamento de Biología, Universidad de Buenos Aires, Ciudad Universitaria Pabellon II, 1428 Buenos Aires, Argentina (MC)

Key words: Oxymycterus rufus, demographic structure, habitat selection, Argentina

\section{Introduction}

Many studies of rodent populations have suggested that population dynamics is influenced by habitat heterogeneity (Hansson 1977, Anderson 1980, Rosenzweig and Abramsky 1980, Stenseth 1980, Lidicker 1985, Ostfeld 1985). In habitats with high food availability and good vegetation coverage, rodent populations show higher density as well as higher persistency, recruitment, and reproductive activity as compared to habitats of lesser quality (Cockburn and Lidicker 1983, Ostfeld et al. 1985, Ostfeld and Klosterman 1986, Young and Stout 1986, Bondrup-Nielsen 1987). Frequently researchers assume that live-trapping grids used to assess population density are homogeneous, and population dynamics can be described through mean values. Łomnicki (1980), however, considers such an approach to be misleading when a correct assessment of population processes is at stake.

The demography of Oxymycterus rufus (Fischer, 1814) populations has been documented in the Pampean area (Dalby 1975). In the delta of the Paraná River Bonaventura et al. (1991) have studied the spatial distribution of $O$. rufus, and 
they could not find factors influencing the habitat selection of this rodent which were related to objective measurements of the quality of such habitats.

Oxymycterus represents one of the rodent genera with morphological characteristics adapted to an insectivorous diet (Carleton 1973). Studies on $O$. rufus' feeding habits suggest this species to be mainly insectivorous even though it also preys on other invertebrates and eats plants (Barlow 1969, Kravetz 1972, Dalby 1975).

This work is aimed at studying the demographic structure of an $O$. rufus population located in the delta of the Paraná River. Effects of habitat heterogeneity and food availability on density, residence, and reproduction of rodents have been analyzed so population phenomena could be assessed in the light of such effects.

\section{Study area and methods}

The study was carried out at Experimental Station INTA "Delta" (Instituto Nacional de Tecnología Agropecuaria), located on an island in the delta of the Paraná River ( $\left.34^{\circ} 09^{\prime} \mathrm{S}, 58^{\circ} 57^{\prime} \mathrm{W}\right)$ in the Province of Buenos Aires, Argentina. Climate is mild and wet with long, hot summers, and harsh freezes in winter. Average annual rainfall is between 900 and $1000 \mathrm{~mm}$ (with lower values during winter). In the lowlands (freshwater marsh) the vegetation is dominated by Scirpus giganteus and S. californicus. On streambanks the "Monte Blanco" woodland (Ocotea acutifolia, Nectandra falcifolia, Rapanea sp.) predominate. Other frequent vegetal formations are Cortaderia selloana meadows, and Baccharis spp. shrublands (Burkart 1957).

Rodent populations were studied using the capture-mark-recapture method using a rectangular grid with 98 trap stations $(14 \times 7) 10 \mathrm{~m}$ apart. A Sherman live trap was placed at each station. The grid worked during three consecutive days monthly between January 1989 and December 1990, and on four other occasions between June and December 1991. Traps were baited with peanut butter, and were inspected every morning. Each $O$. rufus caught was individually identified by two numbered metal ear tags on first capture. For all captures, we recorded trap site, individual identification, gender, reproductive condition (females: vagina open or closed, pregnant, lactating; males: testes scrotal or abdominal), weight, head-body length, and tail length. All animals were released at the site of capture.

Population size was estimated by means of the minimum number of live known animals (MNKA, Krebs 1966). Reproduction intensity was assessed by the proportion of individuals in their reproductive stage (females: vagina open, pregnant, or lactating; males: testes scrotal). Period and duration of the reproductive season were recorded. Based on Anderson's definition of resident individuals (1989), individuals caught in three or more trapping sessions (either consecutive or not) were considered to be residents.

Spatial distribution of $O$. rufus was analyzed by mean capture (MC) recorded per trap in each microhabitat during whole study period. The capture frequency should reflect the intensity of rodents activity in a determined zone of the trapping grid. Use of microhabitat was assessed for each gender through three demographic features: mean capture of total individuals (MC relative density); mean capture of resident individuals (MC residents), and mean capture of breeding individuals (MC reproductives).

Vegetation heterogeneity of the grid was assessed by sampling in $16 \mathrm{~m}^{2}$ plots centered at each trapping station. A complete list of species present, with an abundance-coverage estimate according to Westhoff and Van der Maarel's scale (1978), was obtained for each sampling plot. Plant heterogeneity was assessed by principal component analysis (PCA) (Gauch 1982).

Since $O$. rufus is mainly an insectivorous species (Barlow 1969, Kravetz 1972, Dalby 1975), we have assessed food availability on the basis of the abundance of arthropods. Sampling of surface- 
-dwelling arthropods was performed on a monthly basis in 1990, using 20 pitfall traps (four in each microhabitat), during 15 consecutive days. Traps were constructed of flasks (with a $10 \%$ formalin solution) buried at the soil level (Morris 1960). Arthropods were identified to order (except Hymenoptera among which the family of Formicidae was discriminated). Monthly abundance of arthropods was assessed by calculating a relative density index (RDI = number of caught individuals / number of traps $\times$ number of trapping days). Afterwards RDI was averaged per year.

\section{Results}

\section{Analysis of vegetation and food availability}

The first three components derived from the PCA performed on the plant data matrix explained $85.04 \%$ of variation among trapping stations in connection with species present, and their abundance-coverage values. Component $\mathrm{C} 1$ reflected the tendency of Cortaderia selloana to form patches wherein Baccharis spicata is excluded. C. selloana is a perennial poaceous, $2 \mathrm{~m}$ high grass, forming dense, closely spaced patches. B. spicata is a deciduous shrub and leafless at the base. B. spicata may also reach $2 \mathrm{~m}$ height. C2 and C3 components showed sites where dominant

Table 1. Plant species loadings on the first three components of the principal component analysis, in the delta of the Paraná River, Argentina.

\begin{tabular}{|c|c|c|c|}
\hline \multirow{2}{*}{ Species } & \multicolumn{3}{|c|}{ Principal components } \\
\hline & $\mathrm{C} 1$ & $\mathrm{C} 2$ & C3 \\
\hline Cortaderia selloana & -0.924 & -0.330 & -0.312 \\
\hline Schizachyrium microstachyum & 0.059 & -0.224 & 0.001 \\
\hline Baccharis spicata & 0.852 & -0.473 & -0.502 \\
\hline Pavonia consobrina & 0.244 & -0.110 & -0.102 \\
\hline Panicum grumosum & 0.110 & 0.280 & 0.769 \\
\hline Eupatorium bupleurifolium & 0.009 & -0.005 & -0.006 \\
\hline Calamagrostis viridi-flavescens & 0.307 & -0.224 & 0.011 \\
\hline Panicum sabulorum & 0.277 & -0.228 & 0.114 \\
\hline Ambrosia scabra & 0.309 & -0.120 & 0.009 \\
\hline Eringium sp. & -0.119 & 0.068 & -0.230 \\
\hline Solidago chilensis & 0.265 & -0.054 & 0.238 \\
\hline Cynodon dactylon & 0.150 & -0.299 & 0.010 \\
\hline Carex pseudocyperus & 0.105 & 0.893 & -0.637 \\
\hline Carex bonariensis & -0.120 & 0.231 & -0.001 \\
\hline Juncus microcephalus & 0.030 & 0.509 & -0.212 \\
\hline Cirsium vulgare & 0.026 & 0.062 & 0.097 \\
\hline Glandularia megapotamica & 0.096 & -0.152 & -0.016 \\
\hline Solanum chenopodioides & -0.042 & 0.066 & 0.021 \\
\hline Eupatorium tremulum & -0.178 & 0.022 & 0.298 \\
\hline Calystegia sepium & 0.062 & 0.130 & 0.003 \\
\hline Solanum bonariense & 0.180 & 0.120 & 0.253 \\
\hline Cephalanthus glabratus & -0.002 & 0.330 & 0.279 \\
\hline Alternanthera philoxeroides & -0.003 & 0.122 & 0.093 \\
\hline Percentage of variance account & 50.210 & 25.410 & 9.420 \\
\hline
\end{tabular}




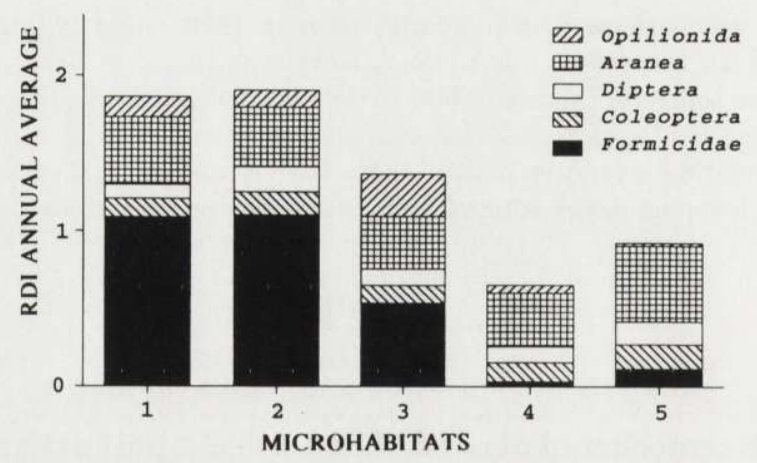

Fig. 1. Relative density index (RDI) annual average of arthropods in each microhabitat (1-5) of the delta of the Paraná River, Argentina. See text for microhabitat definition.

species were Carex pseudocyperus, and Panicum grumosum, respectively. C. pseudocyperus is a perennial, dense, cyperaceous herb some $0.70 \mathrm{~m}$ high, while P. grumosum is a perennial, rhizomatous, poaceous, $1.50 \mathrm{~m}$ high grass (Table 1). Components C1, C2, and C3 allowed five microhabitats on the trap grid to be delimited, in which the dominant species were as follows: microhabitat $1-C$. selloana, microhabitat $2-B$. spicata, microhabitat $3-$ B. spicata and C. selloana, microhabitat 4 - C. pseudocyperus, and microhabitat 5 - P. grumosum.

The most abundant arthropods were: Formicidae, Aranea, Coleoptera, Diptera, and Opilionida (Fig. 1). Total abundance of arthropods varied significantly among microhabitats (Kruskal-Wallis test, $\mathrm{H}=10.99, p<0.05$ ). Microhabitats 4 and 5 showed a significantly lower abundance of arthropods (Dunn test for multiple non-parametric comparison, $p<0.05$ ). Abundance of Formicidae and Opilionida varied among microhabitats (Kruskal-Wallis test, $\mathrm{H}=25.17, p<0.001$, and $\mathrm{H}=$ $13.34, p<0.01$, respectively; Fig. 1). Microhabitats 2 and 1 evidenced the largest abundance of Formicidae (Dunn test for multiple non-parametric comparison, $p<$ 0.05 ), and microhabitats 3 and 1 evidenced the largest abundance of Opilionida $(p<0.05)$.

\section{Population demography and dispersion of $O$. rufus}

Altogether 225 individuals were captured 558 times between January 1989 and December 1991. MNKA was remarkably constant over the entire study, varying from a low of 9 individuals in September 1990 to a high of 26 individuals in June 1991 (Fig. 2). O. rufus reproductive activity was seasonal: reproducting individuals were caught only in spring and summer (Fig. 2).

From Table 2, the spatial distribution of males, females, and total population (both males and females together) of $O$. rufus in the three demographic categories for each microhabitat can be seen. Two factors ANOVA (microhabitats and gender; Sokal and Rohlf 1981) for MC relative density and MC residents showed that microhabitats use between gender was not significantly different (interaction effect, MC relative density: $F=1.46, \mathrm{df}=4,110, \mathrm{~ns} ; \mathrm{MC}$ residents: $F=1.71, \mathrm{df}=4,110, \mathrm{~ns}$; 


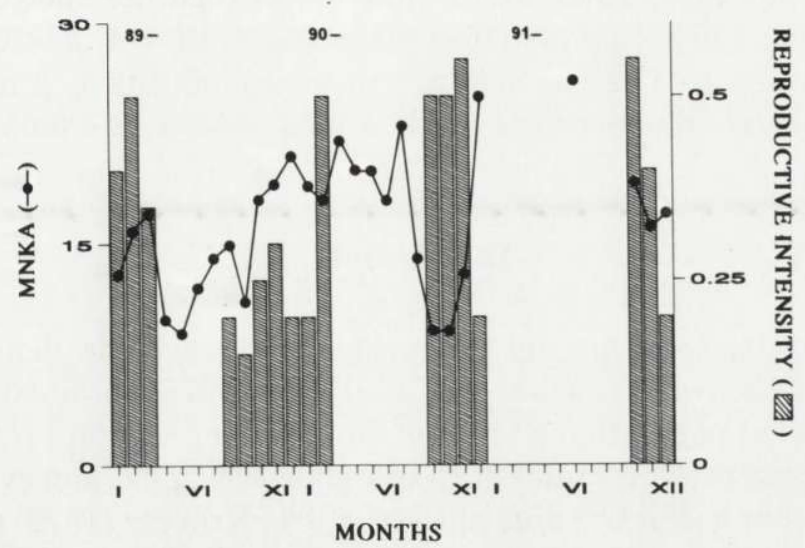

Fig. 2. Monthly variation of population size (MNKA) and reproductive intensity of Oxymycterus rufus in the delta of the Paraná River, Argentina.

Table 2). All individuals together showed a differential spatial distribution (microhabitat effect, MC relative density: $F=5.14, \mathrm{df}=4,110, p<0.005$; MC residents: $F=5.52$, $\mathrm{df}=4,110, p<0.005$; Table 2). Differences observed were due to a higher capture in microhabitat 1, 2 and 3 than in 4 and 5 (Scheffé's contrasts test, MC density: $S=$ 4.12, $\mathrm{df}=1, p<0.005$; MC residents: $S=4.80, \mathrm{df}=1, p<0.005$; Table 2).

Since many data transformations of MC reproductives were insufficient to use parametric tests, data were analysed by means of a non-parametric two factors ANOVA (microhabitat and gender; Scheirer et al. 1976). MC reproductives showed that microhabitat use between gender were not significantly different (interaction

Table 2. Mean capture (MC) of males, females, and total population of Oxymycterus rufus in the three demographic categories for each microhabitat in the delta of the Paraná River, Argentina.

\begin{tabular}{lccccc}
\hline & \multicolumn{5}{c}{ Microhabitats } \\
\cline { 2 - 6 } Demographic categories & 1 & 2 & 3 & 4 & 5 \\
\hline MC relative density & & & & & \\
$\quad$ Males & 1.05 & 1.49 & 1.59 & 0.93 & 0.67 \\
$\quad$ Females & 1.44 & 1.20 & 1.09 & 0.68 & 0.67 \\
$\quad$ Total & 2.49 & 2.69 & 2.68 & 1.61 & 1.34 \\
MC residents & & & & & \\
$\quad$ Males & 0.57 & 0.84 & 1.05 & 0.47 & 0.46 \\
$\quad$ Females & 1.14 & 0.83 & 0.90 & 0.38 & 0.42 \\
$\quad$ Total & 1.71 & 1.67 & 1.95 & 0.85 & 0.88 \\
MC reproductives & & & & & \\
$\quad$ Males & 0.09 & 0.07 & 0.11 & 0.02 & 0.00 \\
$\quad$ Females & 0.12 & 0.09 & 0.10 & 0.06 & 0.00 \\
$\quad$ Total & 0.21 & 0.16 & 0.21 & 0.08 & 0.00 \\
\hline
\end{tabular}


effect: $\mathrm{H}=1.11, \mathrm{df}=4$, ns; Table 2). All individuals together showed a differential spatial distribution (microhabitat effect: $\mathrm{H}=26.74, \mathrm{df}=4, p<0.001$; Table 2). Differences were due to a higher capture in microhabitats 1,2 and 3 than in 4 and 5 (non-parametric linear contrasts: $\mathrm{H}=6.53, \mathrm{df}=1, p<0.05$. Table 2).

\section{Discussion}

During the study, $O$. rufus did not evidence remarkable density variations, although reproduction was seasonal (Fig. 2). Dalby (1975) obtained similar results as regards $O$. rufus' population variation in the Pampean area. Such demographical characteristic could be related to a higher ecological longevity of $O$. rufus. When analyzing changes in $O$. rufus age structure, Kravetz (1972) considered that most individuals could live through at least two reproductive seasons, and in the present research some individuals persisted more than 24 months (V. R. Cueto, unpubl.). This observation suggests that $O$. rufus' ecological longevity could be two years, thus causing an overlapping of at least two generations, hence reducing density variation. Besides, $O$. rufus' persistence would be favored by two characteristics aimed at discouraging predators, namely tail autotomy (Dalby 1975), and secretion of unpleasant odors (Barlow 1969). Such evidence for low predation is reinforced when observing how few remnants of $O$. rufus are found in owl pellets (Massoia and Fornes 1964, Dalby 1975).

$O$. rufus spatial distribution varied among the microhabitats present on the area under study. Density, residence and reproduction of both sexes were higher in microhabitats 1,2 , and 3, but lower in microhabitats 4 and 5. Food resources and plant cover are important to most rodents populations (Birney et al. 1976, Taitt and Krebs 1983). However, O. rufus is not dependent on the floristic composition of the microhabitats, because it uses sites dominated by grass (eg C. selloana) or shrubs (eg B. spicata). Bonaventura et al. (1991) observed that reproductive individuals of $O$. rufus were not associated with the foliage availability. Considering O. rufus is mainly an insectivorous rodent (Barlow 1969, Kravetz 1972, Dalby 1975), the use of the microhabitats 1,2 , and 3 is likely to be due to the fact that such sites are more favorable for feeding on account of the greater availability of arthropods (Fig. 1). Several field studies suggest that this is a common behaviour among small rodents (Cole and Batzli 1979, Cockburn and Lidicker 1983, Ostfeld and Klosterman 1986, Bondrup-Nielsen 1987, Batzli and Lesiutre 1991).

Ants contributed most to the differences in the abundance of arthropods among habitats since they were more abundant in microhabitats 1,2 , and 3 than in 4 and 5 (Fig. 1). O. rufus has been classified as a myrmecophagous species (Redford 1987), and hence could be supposed that the spatial distribution of this species is in keeping with the ant availability in the above mentioned microhabitats. Even though ants are not more nutritive than other arthropods (Redford and Dorea 1984), they are found in large groups, thus creating a "concentrated" food source. 
Ants would be a very abundant nourishing item with a constant location (their nests) thus being a more predictable food source than other arthropods. Churchfield (1980) has observed that, whenever prey are closely spaced, shrews (Sorex araneus) go back time and time again to the site until it is totally depleted. Ants as the sole food item in the stomach is a characteristic of O. rufus (Kravetz 1972, O. V. Suarez, pers. comm.). We suspect that this species is likely to feature a behavior similar to that of shrews, as pointed out by Churchfield (1980) when looking for food. Morever, $O$. rufus have strong fore-claws and a shrew-like pointed snout apt to digging and rooting among (Dalby 1975), so it is well adapted to attack ant nests.

The results of the present study suggest that microhabitat use has important consequences in life history of $O$. rufus. This suggests that objective measurements of habitat variation should be performed in order to clarify $O$. rufus' habitat selection. Our results emphasize the importance of food availability in the spatial distribution of resident and reproductive individuals, and hence in the survival and breeding success of their populations in the Paraná delta area.

Acknowledgements: We are grateful to O. P. Pearson, J. N. López de Casenave and O. Vaccaro, for reading and commenting on the manuscript. Early versions of this manuscript were improved by comments of anonymous reviewers. We appreciate the help and hospitality of Director and technicians of the Experimental Station INTA "Delta". We thank M. I. Sánchez López and S. M. Bonaventura for assistance in the field. Research was supported by a grant from the Consejo Nacional de Investigaciones Cientificas y Técnicas de la República Argentina (CONICET, Grant PID No. 3038200-85).

\section{References}

Anderson P. K. 1980. Evolutionary implications of microtine behavioral systems on the ecological stage. Biologist 62: 70-88.

Anderson P. K. 1989. Dispersal in rodents: a resident fitness hypothesis. Special Publications of American Society of Mammalogy 9: 1-141.

Barlow J. C. (1969). Observations of the biology of rodents in Uruguay. Life Sciences Contributions Royal Ontario Museum 75: 1-59.

Batzli G. O. and Lesiutre C. 1991. The influence of high quality food on habitat use by arctic microtine rodents. Oikos 60: 299-306.

Birney E. C., Grant W. E. and Baird D. D. 1976. Importance of vegetative cover to cycles of Microtus populations. Ecology 57: 1043-1051.

Bonaventura S. M., Piantanida M. J., Gurini L. and Sánchez López M. I. 1991. Habitat selection in population of cricetine rodents in the region Delta (Argentina). Mammalia 55: 339-354.

Bondrup-Nielsen S. 1987. Demography of Clethrionomys gapperi in different habitats. Canadian Journal of Zoology 65: 167-177.

Burkart A. 1957. Ojeada sinoptica sobre la vegetación del Delta del Río Paraná. Darwiniana 11: 457-561.

Carleton M. D. 1973. A survey of gross stomach morphology in New World Cricetinae (Rodentia, Muroidea), with comments on functional interpretations. Miscellaneous Publications Museum of Zoology, University of Michigan 146: 1-43.

Churchfield S. 1980. Subterranean foraging and burrowing activity of the common shrew, Sorex araneus L. Acta Theriologica 25: 451-459. 
Cockburn A. and Lidicker W. Z., Jr 1983. Microhabitat heterogeneity and population ecology of an herbivorous rodents, Microtus californicus. Oecologia 59: 167-177.

Cole F. R. and Batzli G. O. 1979. Nutrition and population dynamics of the prairie vole, Microtus ochrogaster, in central Illinois. Journal of Animal Ecology 48: 455-470.

Dalby P. L. 1975. Biology of Pampa rodents, Balcarce area, Argentina. Publications of the Museum of Michigan State University, Biological Series 5: 149-271.

Gauch H. G., Jr 1982. Multivariate analysis in community ecology. Cambridge University Press, Cambridge: 1-298.

Hansson L. 1977. Spatial dynamics of field voles Microtus agrestis in heterogeneous landscapes. Oikos 29: 539-544.

Kravetz F. O. 1972. Estudio del régimen alimentario, períodos de actividad y otros rasgos ecológicos en una población de "ratón hocicudo" (Oxymycterus rufus platensis, Thomas) de Punta Lara. Acta Zoologica Lilloana 29: 201-212.

Krebs C. J. 1966. Demographic changes in fluctuating populations of Microtus californicus. Ecological Monographs 36: 239-272.

Lidicker W. Z., Jr 1985. Population structuring as a factor in understanding microtine cycles. Acta Zoologica Fennica 173: 23-27.

Łomnicki A. 1980. Regulation of population density due to individual differences and patchy environment. Oikos 35: 185-193.

Massoia E. and Fornes A. 1964. Pequeos mamíferos (Marsupialia, Chiroptera y Rodentia) y aves obtenidos en regurgitados de lechuzas (Strigiformes) del Delta bonaerense. Investigaciones Agropecuarias Delta del Paraná 6: 27-34.

Morris R. F. 1960. Sampling insect populations. Annual Review of Entomology 5: 243-263.

Ostfeld R. S. 1985. Limiting resources and territoriality in microtine rodents. American Naturalist 126: $1-15$.

Ostfeld R. S. and Klosterman L. L. 1986. Demographic substructure in a California vole population inhabiting a patchy environment. Journal of Mammalogy 67: 639-704.

Ostfeld R. S., Lidicker W. Z., Jr and Heske E. J. 1985. The relationship between habitat heterogeneity, space use, and demography in a population of California voles. Oikos 45: 433-442.

Redford K. H. 1987. Ants and termites as food: patterns of mammalian myrmecophagy. Current Mammalogy 1: 349-399.

Redford K. H. and Dorea J. G. 1984. The nutritional value of invertebrates with emphasis on ants and termites as food for mammals. Journal of Zoology, London 203: 385-395.

Rosenzweig M. L. and Abramsky A. 1980. Microtine cycles: the role of habitat heterogeneity. Oikos 34: 141-146.

Scheirer C. J., Ray W. S. and Hare N. 1976. The analysis of ranked data derived from completely randomized factorial designs. Biometrics 32: 429-434.

Sokal R. R. and Rohlf F. J. 1981. Biometry. 2nd ed. W. H. Freeman, New York: 1-859.

Stenseth N. C. 1980. Spatial heterogeneity and population stability: Some evolutionary consequences. Oikos 35: 165-184.

Taitt M. J. and Krebs C. J. 1983. Predation, cover, and food manipulations during a spring decline of Microtus towsendii. Journal of Animal Ecology 52: 837-848.

Westhoff V. and Maarel E., van der 1978. The Braun-Blanquet approach. [In: Classification of plants communities. R. H. Whittaker, ed]. Dr W. Junk, The Hague: 287-399.

Young B. L. and Stout J. 1986. Effects of extra food on small rodents in a south temperate zone habitat: demographic responses. Canadian Journal of Zoology 64: 1211-1217.

Received 12 September 1994, accepted 18 March 1995. 